\title{
A London Residential Retrofit Case Study: Evaluating passive mitigation methods of reducing risk to overheating through the use of solar shading combined with night-time ventilation.
}

\author{
Zoe De Grussa ${ }^{1}$, Dr Deborah Andrews ${ }^{1}$, Dr Gordon Lowry², Dr Elizabeth .J. Newton ${ }^{3}$, \\ Kika Yiakoumetti ${ }^{2}$, Andrew Chalk ${ }^{4}$ and David Bush ${ }^{4}$ \\ ${ }^{1}$ London South Bank University, School of Engineering \\ ${ }^{2}$ London South Bank University, School of The Built Environment and Architecture \\ ${ }^{3}$ London South Bank University, School of Applied Sciences \\ ${ }^{4}$ The British Blind and Shutter Association
}

\begin{abstract}
Overheating in the indoor environment, specifically in domestic homes, schools and healthcare settings has become of great concern to us in the UK. This is due to frequent hot weather events as a result of the continually rising global average temperatures. Overheating is a result of the heat gains associated with occupancy and solar heat gains trapped in the internal environment. The continuing rise in global average temperatures and improved insulation standards necessary to mitigate heat losses during the winter, in conjunction with poorly planned ventilation strategies, are exacerbating overheating during warmer weather conditions. In the last decade there has been a considerable improvement in reducing heat gains associated with occupancy (from lighting and equipment) thus making solar heat gains more prominent in contributing to overheating. With the rise in the number of buildings that overheat and the rise in the number of associated deaths these contribute to, it is now crucial that passive measures are utilised appropriately, and for building occupants to be educated in how to safeguard their homes against overheating.
\end{abstract}

This research is centered around a real-world monitoring case study and investigates how the proposed passive measures can mitigate overheating risk. These measures include the use of different internal and external solar shading devices combined with a night-time natural ventilation strategy. This study was conducted in a south-west facing, single aspect retrofit apartment building in London between August and October 2016 and 10-minute interval data was collected during the daytime over twenty days. Throughout the monitoring period, a controlled window opening strategy was applied in rooms where differing shading strategies were implemented. In the absence of nighttime measurements, the rooms were evaluated according to CIBSE TM52 Overheating Criteria to assess the frequency and the severity of overheating and mitigation methods were statistically compared to analyse the difference in internal operative temperature increase according to the type of passive mitigation scenario implemented.

The combination of opening windows at night and the closure of shading devices during the day can provide a significant thermal benefit to occupants. The inter-relationship between glazing, shading, ventilation amongst other variables need to be collectively evaluated at the building design stage to ensure the appropriate design of an effective façade management strategy.

\section{Keywords:}

Overheating, Solar Shading, Night-Time Ventilation, Blinds, Retrofit, Human Comfort

\section{Corresponding Author:}

Email: degrussz@lsbu.ac.uk 


\section{Practical Application}

This study aims to add to the body of knowledge surrounding overheating by investigating the impact that the combination of shading and night-time ventilation strategies can have on a newly refitted, urban apartment. It demonstrates how the frequency; severity and the absolute maximum temperature can be identified using existing industry criteria and then uses this methodology alongside inferential statistics to compare the effectiveness of differing shading strategies when combined with night purge ventilation.

\section{Introduction}

Increasing global temperatures put buildings in the UK at risk of overheating ${ }^{1}$ and $20 \%$ of the housing stock is currently subject to overheating ${ }^{2,3}$. Most concerningly, $90 \%$ of hospitals are susceptible to overheating ${ }^{4}$. The Climate Change Risk Assessment Report, 2017 warns that the UK currently 'has no comprehensive policies in place to adapt existing homes and other buildings to high temperatures, manage urban heat islands, nor safeguard new homes. ${ }^{1}$.

More recently the Environmental Audit Committee (2018) put together evidence to government that identified the health risks of heatwaves and the reasons why change was needed $^{5}$. The most notable evidence to health was the impact of the 2003 heatwave. This lasted 10 days in the UK and caused 2,193 heat-related deaths which is predicted to triple by 2050 . Those most vulnerable to heatwaves are individuals who have poor thermoregulatory systems or are unable to improve their thermoregulation typically the elderly, infants, those with disabilities or chronic illnesses. All individuals are limited in their ability to protect themselves when sleeping and night-time temperatures in excess of $24^{\circ} \mathrm{C}$ are of particular concern as thermal discomfort and quality of sleep begin to deterioriate ${ }^{6}$.

The Building Research Establishment (BRE) surveyed 2,616 households and found that over $40 \%$ of the households that experience overheating attribute this to 'insufficient shading' ${ }^{3}$. When reviewing differing building typologies, urban apartments have been identified to overheat most frequently ${ }^{5,7}$. The Good Homes Alliance assessed 90 instances of overheating in domestic buildings in the UK and $73 \%$ of these were situated in urban locations. $78 \%$ (of the 90 ) of these occurrences were reported in apartments, $48 \%$ (of the 90 ) were new builds (30\% had been built post 2000 ) and $30 \%$ were buildings repurposed/refitted into apartments ${ }^{7}$.

The Energy Performance of Building Directive recommends passive measures to tackle overheating, such as solar shading, to avoid the need for and reduce the size of air conditioning units and thereby reduce energy consumption ${ }^{8,9}$. In the UK air conditioning systems are still rarely used within domestic homes, however this may change with the expected increase in heat waves in years to come ${ }^{10,11}$. Research has been carried out to predict the increase in mean daily maximum temperatures in the UK for 2080's medium emission scenario. In the South-East of England these are likely to be the largest resulting in a $4.2^{\circ} \mathrm{C}$ increase from the $1961-1980$ 's baseline (representative of a $50 \%$ probability level) ${ }^{12}$. Within research literature a recent paper by Lomas and Porritt ${ }^{13}$, reviews 12 studies where overheating has been evidenced across the UK in domestic homes in a mix of building types that vary in age and construction type. It was concluded that the term 'overheating' is not clearly defined for post-occupancy evaluations as differing methodologies, data collection procedures and measurements are used within research which makes comparisons between them problematic.

The Chartered Institution of Building Services Engineers (CIBSE) recommends two of the most widely known methods of evaluating overheating risk within naturally ventilated and 
mechanically ventilated buildings which cover differing building typologies. CIBSE TM52 ${ }^{14}$ addresses all building typologies through a three criteria assessment process that was developed for the early design stage of a building where building modelling is employed. This method is also recommended to be used in real-world measurement scenarios which require data collection of internal operative temperatures and external air temperatures over a period of at least 10 days that are representative of weather conditions ${ }^{6}$.

The three criteria system aims to assess the frequency, severity and set an absolute maximum temperature for overheating. Two of the following three criteria must be satisfied to avoid overheating risk:

1. Sets a limit for the number of hours that the operative temperature can exceed the adaptive comfort threshold defined by BS EN 15251. This should not exceed 1 Kelvin (K) for more than $3 \%$ of hours in the non-heating season.

2. Reviews the severity of the overheating within any one day. This criterion assesses the weighted exceedance in relation to the adaptive comfort threshold and should be less than or equal to 6 degree-hours (K.hr) in any individual day.

3. Sets an absolute maximum daily temperature. Where the maximum acceptable operative temperature $\left(T_{\max }\right)$ should not be exceeded by $4 \mathrm{~K}$ and is termed $T_{\text {upp }}$.

Additionally, Criteria 2 and 3 are not constrained to the summer period which is defined as May to September 6 and criterion 1. is limited to the 'occupied' hours for building modellers, but this is not defined in post-occupancy evaluations due to the acknowledged difficulties surrounding data collection.

The more recently developed CIBSE TM59 ${ }^{15}$ methodology specifically addresses overheating risk in homes. Buildings are required to meet two criteria which are dependent on room type i.e. bedroom, living room and kitchen. Criterion 1 in CIBSE TM52 is common between the two methodologies and is referred to as criterion A. Bedrooms, living rooms and kitchens should be assessed against this criterion. Criterion B places further emphasis on bedrooms and highlights the importance of comfort during sleeping hours. It sets a more stringent limit on the number of hours and the severity of overheating. The operative temperature threshold is reduced to $26^{\circ} \mathrm{C}$ and this should not be exceeded for more than $1 \%$ of annual hours between the hours of $10 \mathrm{pm}$ and $7 \mathrm{am}$.

In addition, TM59 strongly recommends alternative occupancy profiles should be used for building modelling analysis. A 24-hour occupancy profile should be assumed for bedrooms and in relation to a two-bedroom flat at least one person should be assumed in each bedroom in the daytime and two people in each double bedroom at night. Window openings are also addressed where windows should be assumed open when the dry bulb internal temperatures exceed $22^{\circ} \mathrm{C}$. This method addresses the unpredictability of occupant behavior and accounts for the fact that a growing number of occupants now work from home and more vulnerable occupants are more likely to be at home in the daytime ${ }^{16,17}$.

In real-world studies, simulating or recording occupant behaviours (e.g. window opening and blind movements) can be problematic. Methods such as relying on occupant surveys, photographing the outside of buildings and using dataloggers to collect data are frequently used. However these too are not always appropriate, reliable and can be costly ${ }^{18,19}$. Alternatively test houses have been setup in the UK that use automated systems and sensors to replicate occupancy profiles ${ }^{20}$. 
Increased ventilation and solar shading are widely recommended strategies for combatting overheating ${ }^{21-24}$. In prior research dynamic external shading is valued as one of the most effective methods of reducing overheating and energy costs ${ }^{9,25-29}$. However, many of these studies have been carried out using building simulation tools and very few real-world studies have been conducted and fewer still that have been carried out in the UK. Some raise uncertainties about the reliability of building simulation tools. Therefore more recently there has been an increase in the number of real world studies being conducted ${ }^{13}$.

Dynamic solar shading has been found to be effective at reducing overheating and improving energy efficiency in comparison to fixed shading systems ${ }^{9,30-32}$. This can be achieved through extending (closing) solar shading devices to reject unwanted solar gains in hotter weather and then retracting (opening) solar shading in colder weather to allow valuable solar gains to enter and heat our buildings, reducing subsequent heating energy costs. Further to this they can be closed at night in colder months to reduce the amount of heat escaping through the window area ${ }^{9,30-32}$. A study carried out by Dubois ${ }^{33}$ investigated the differences in energy savings when a fixed awning was positioned year round on a south facing window in Stockholm and when a seasonal awning was only used in summer. The seasonal awning reduced annual cooling energy by $80 \%$ where the fixed awning increased heating by $31 \%$.

The barriers to dynamic solar shading and increased ventilation are those of human behaviour. It has been suggested in the UK Climate Change Risk Assessment $2017^{1}$ that "...people lack a basic understanding of the risks to health from indoor high temperatures and are therefore less likely to take measures to safeguard their and their dependents' wellbeing.".

Natural ventilation in urban areas can be problematic due to issues arising from external noise and security concerns. In a survey given to 89 householders in London, windows were found to be used infrequently with over half of respondents stating they were unable to open windows due to security reasons and one third asserting they were unable to open them due to high external noises. Furthermore, over the course of a very hot day one in five respondents would not tend to open any windows at night and one in ten would keep all windows closed all day ${ }^{18}$. Acoustic design guidance has only recently been provided to industry in relation to overheating ${ }^{34}$.

Blinds and shutters are also used infrequently and the motivations to instigate blind movements are often related to a number of factors inclusive of lighting conditions, exposure to glare, preference for a view and the associated thermal affects which are then defined by the priorities of the user ${ }^{35,36}$. Even on seemingly hot days occupants do not necessarily close blinds during particularly hot periods of the year ${ }^{18}$.

Building regulations, Approved Document Part L1A, currently encourage housebuilders to make "reasonable provision to limit heat gains" but they do not set a specific criteria or threshold that needs to be met. The Standard Assessment Procedure (SAP) compliance tool does include an overheating 'check' that allows designers to demonstrate that reasonable provision has been made but these do not impact the final SAP rating ${ }^{37}$. Therefore, both Part L1A and SAP are ineffective in capturing the benefits of passive design and do not encourage designers to consider overheating risk ${ }^{5,21,25,38}$. However, as $75-90 \%$ of the buildings have already been built and will still be standing in 2050 it is also important for industry to understand the impact that retrofit options have on health and well-being, comfort, energy consumption and the building fabric ${ }^{11}$. 
In this study, we aim to add to this body of knowledge by investigating the impact that a combination of shading and night-time ventilation strategies can have on a newly refitted, urban apartment. We first assess the frequency, severity and whether the absolute maximum temperature is exceeded using existing industry criteria to identify overheating risk and then use this methodology alongside inferential statistics to compare the effectiveness of differing shading strategies when combined with night purge ventilation.

\section{Case Study Methodology}

This building was investigated as during the construction process it was reported that some of the apartments appeared to be overheating above acceptable comfort levels. This caused issues for workers carrying out the re-fit as the increased heat affected materials and construction methods.

The apartment building is in North London and was originally built in the 1930s for the manufacture of aircraft parts. In the 1980's it was converted into offices ${ }^{39}$ and has now more recently, in 2014, been converted into twenty residential loft apartments and two penthouse suites. The renovation was carried out between 2015 and 2016 in accordance with UK Building Regulations (2010).

The south-west façade of the building is situated on a busy main road in the heart of Camden with a 24-hour use bus stop directly in front of the property. Little external shading is provided although a communal garden area was developed at the front of the building which consists of a $1.8 \mathrm{~m}$ wooden fence surround containing newly planted young evergreen oak trees that provide privacy and shading to the ground floor apartments and potentially the first floor of the building in years to come (Figure 1.). Additionally, the building thermal mass was considered light weight according to the SAP methodology. The construction is a mix of brick, concrete and timber flooring throughout the building.

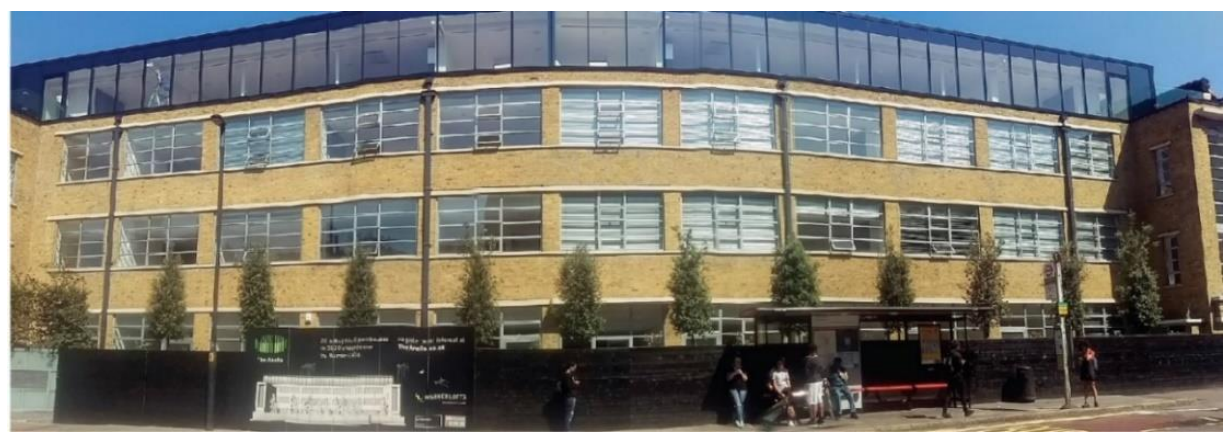

Figure 1. South-West facing building close to Camden High Street Underground Station

(Photograph was taken with a wide-angled lens).

In the original building specification, no shading was specified, and no $g$ value was provided for the glazing. Due to the substantial size of the glazed façade the research team hypothesised that a solar heat gain reduction (achieved through installing solar shading) would result in the decrease of internal temperatures throughout the day and these would be closer (or within) the comfort thresholds.

Access to the case study building was granted by the building contractor between the hours of $8 \mathrm{am}$ and $4 \mathrm{pm}$. Therefore, for this case study, we have modelled the real-time behaviour of an occupant who leaves their home vacant between $8 \mathrm{am}$ and $4 \mathrm{pm}$ by keeping the windows closed for security reasons during the day. We then assessed the thermal 
impact of closing an internal or external blind for the duration of 24 hours, whilst opening windows overnight to allow for night purge ventilation.

The operative temperatures were monitored in each of the rooms at 10-minute intervals using manual sensors. In each of the rooms a different solar shading strategy was used and combined with night time ventilation. The recorded operative temperatures with in the non-shaded and shaded rooms were evaluated based on CIBSE TM52 ${ }^{14}$. Due to the use of manual sensors and the time restrictions on access to the building it was not possible to evaluate the internal night-time temperatures in relation to CIBSE TM59 ${ }^{15}$. The number of hours when overheating occurred in relation to the adaptive comfort thresholds, the severity of the overheating and how often the rooms exceeded the absolute maximum temperature thresholds with internal shading, external shading and without shading were measured, are evaluated and compared.

In addition, the temperature increase $(\Delta T)$, or temperature difference, from the start of the day to the end of the day was compared statistically between the control room (without a shading device), and the test rooms, with either an internal or external shading device.

\section{Monitored Apartments}

The twenty apartments were spread over four floors between the basement level to the second floor. The central apartments on the $1^{\text {st }}$ and $2^{\text {nd }}$ floor (Apartment 13 and 18) were selected for monitoring as the internal layouts were identical, they had the same orientation and the external shading provided by neighbouring buildings and overhangs was almost identical (Figure 2). Therefore, the external façade of the apartments was exposed to similar weather conditions.

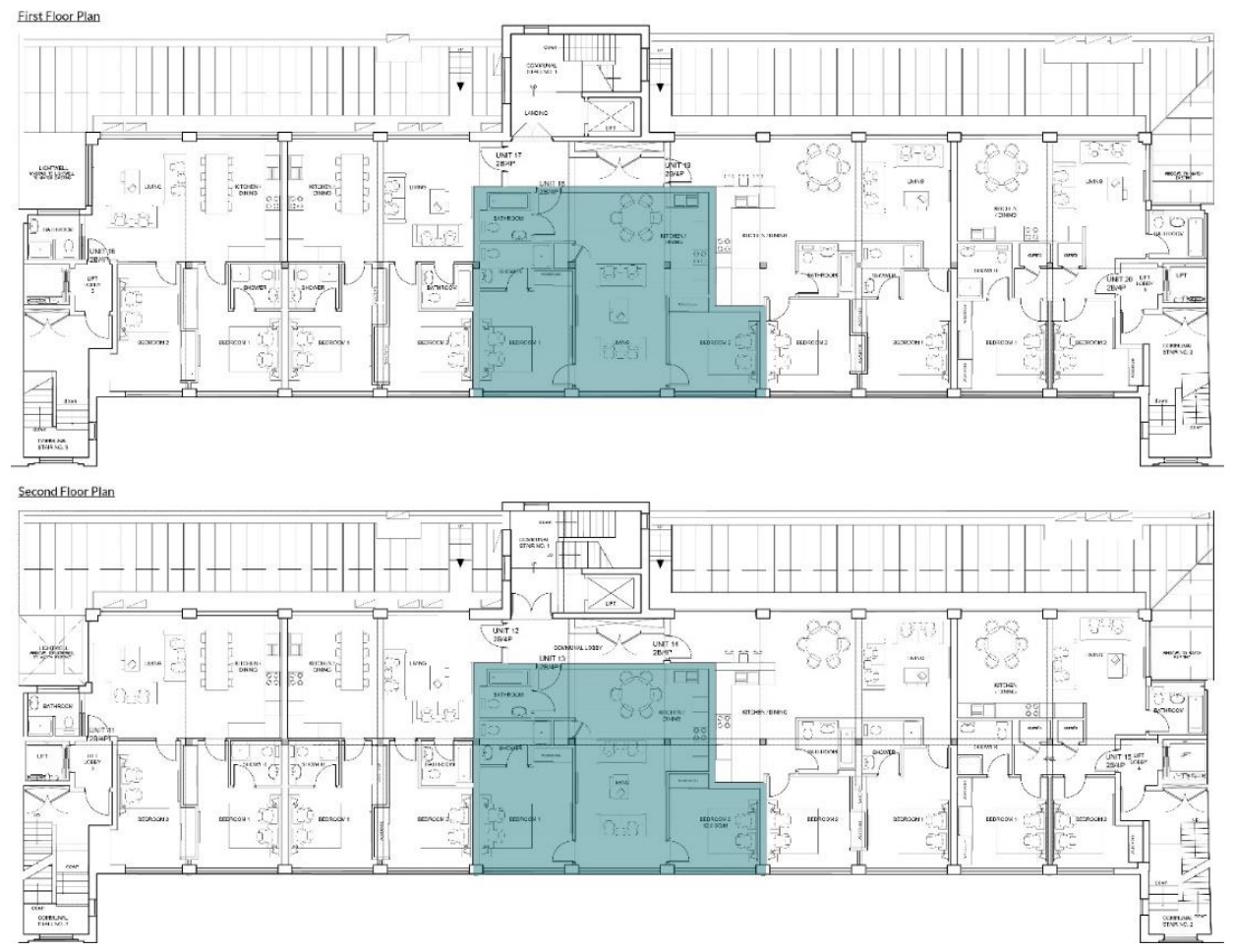

Figure 2. (Above) First Floor (Below) Second Floor Building Layout 
The selected apartments highlighted in Figure 2 show the single aspect design with a highly glazed façade to the south-west. Each apartment contains a living room, kitchen, bathroom and two rooms designed as bedrooms on the south-west side of the building which is illustrated in Figure 3 .

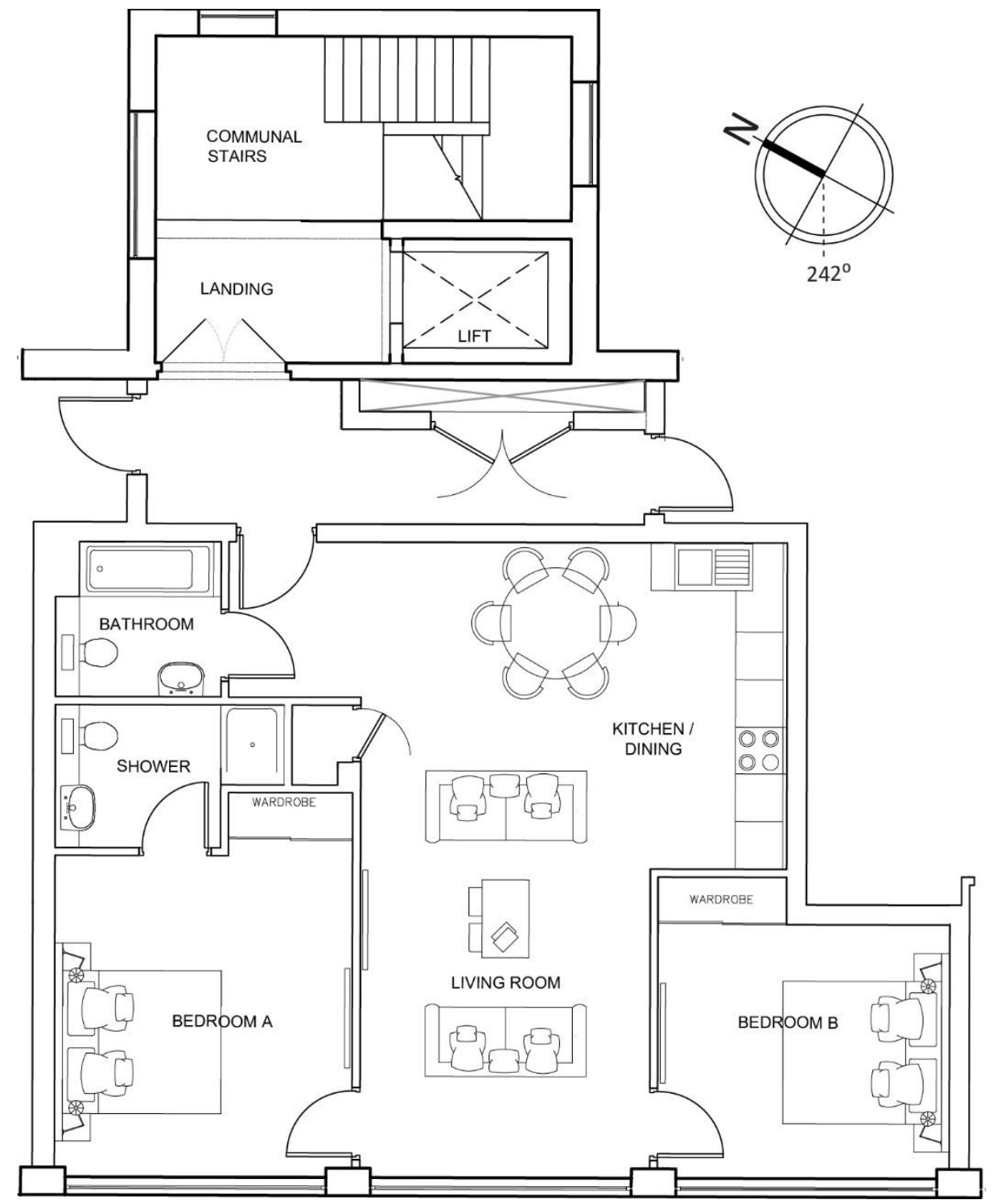

Figure 3. Apartment 13 and 18 Layout

The two bedrooms in both apartments were selected for monitoring as there were no differences between the rooms other than the room depth, Bedroom $A$ is $4.5 \mathrm{~m}$ deep whereas Bedroom $B$ extends to $3.5 \mathrm{~m}$. The ceiling height was $2.6 \mathrm{~m}$ and the room width was $3.5 \mathrm{~m}$. The walls and floors were finished and painted to the same standard - matt white paint on the walls and oak wood flooring and there was no furniture in either apartment.

\section{Façade Design}

Each of the bedrooms had a glazed area that had been refitted during refurbishment with double Low-E argon filled glazing (4-16-4) with a black/grey spacer which fitted into a steel mullion framework. The glazed areas were of equal size covering $3200 \mathrm{~mm} \times 1850 \mathrm{~mm}$ with less than $13 \%$ of the area openable via two top hung windows $(850 \mathrm{~mm} \times 450 \mathrm{~mm}$ ) located in the centre column (Figure 4). 


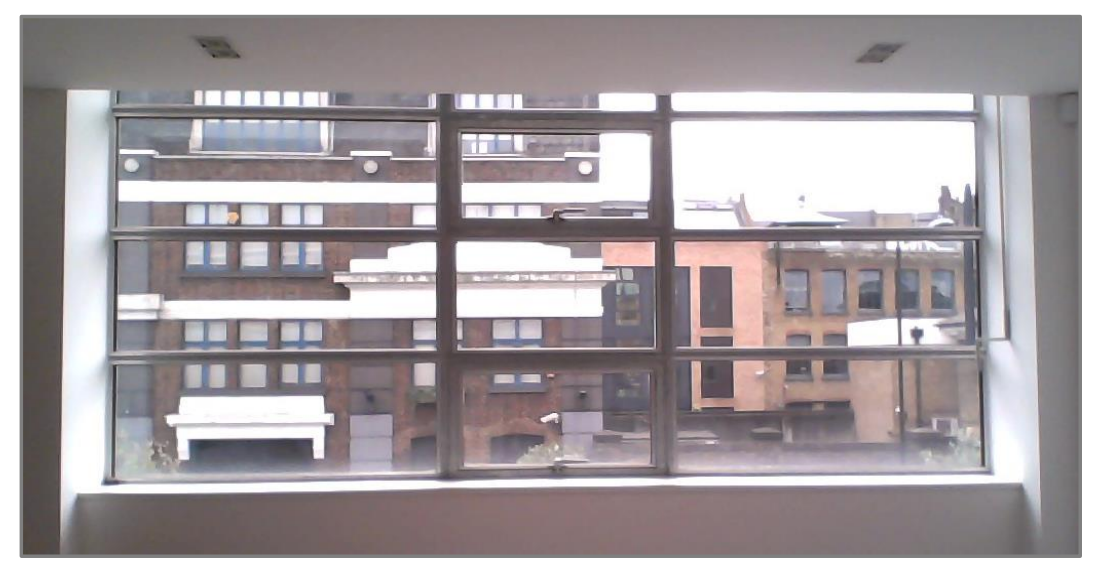

Figure 4. Apartment 13 Window View

\section{Solar Shading Products Tested}

During the experiment the impact of three internal and two external solar shading products were tested. The impact of the venetian blind was tested when at a $45^{\circ}$ and fully closed.

\section{Internal Shading}

- Aluminium venetian blind (Fully closed)

- Aluminium venetian blind (Angled at $45^{\circ}$ )

- Screen fabric roller blind

- Reflective screen fabric roller blind

\section{External Shading}

- Aluminium Venetian blind (Fully closed)

- Aluminium Venetian blind (Angled at $45^{\circ}$ )

- Screen fabric roller blind

The solar properties of each blind type are presented in Table 1 and calculated to BS EN 14501:2005 ${ }^{40}$. Even though the g tot could not be calculated due to lack of glazing data, this has not compromised the study as the same type and size of glazing was used in each of the rooms.

\begin{tabular}{lllll}
\hline Blind Fabric & $\begin{array}{l}\text { Material } \\
\text { Composition }\end{array}$ & $\begin{array}{l}\text { Solar } \\
\text { Transmission } \\
\text { (Ts / te) }\end{array}$ & $\begin{array}{l}\text { Solar } \\
\text { Reflectance } \\
\text { (Rs / pe) }\end{array}$ & $\begin{array}{l}\text { Solar } \\
\text { Absorptance } \\
\text { (As / ae) }\end{array}$ \\
\hline Aluminium Venetian & Aluminium (80mm Slats) & 0.00 & 0.50 & 0.50 \\
\hline $\begin{array}{l}\text { Aluminium Venetian } \\
\text { at 45 } \text { Angle }\end{array}$ & Aluminium (80mm Slats) & 0.08 & 0.38 & 0.55 \\
\hline Screen Fabric & 42\% Fibreglass / 58\% PVC & 0.10 & 0.20 & 0.70 \\
\hline Reflective Screen Fabric & $36 \%$ Fibreglass / 64\% PVC & 0.05 & 0.76 & 0.19 \\
\hline
\end{tabular}




\section{Occupancy}

During the investigation the window opening behaviours of an occupant who goes to work during the day were simulated. The apartment would be unoccupied between 8 am and 4 pm with windows closed for security reasons during the day. Between $4 \mathrm{pm}$ and 8 am windows were then opened, as though the apartment were occupied, which enables occupants to take advantage of the cooler external temperatures at night to ventilate the building. It was only feasible to test one occupancy profile within the time given for data collection.

\section{Data Collection Procedure}

The data was collected over twenty days between August and October 2016. Before each day of data collection, the windows and joining internal room doors between the bedrooms and living areas were left open overnight to allow for night-time cooling. Prior to the day of data collection a different shading device was installed in each room, except for the control room where no blind was installed.

Data collection procedure:

- 8 am - Windows and doors closed, measurements start.

- Operative and Air Temperature measurements were taken every 10 minutes.

- 4 pm - Windows and doors opened, measurements stopped.

The measurements were manually collected which required a researcher to enter each room and record the readings on the sensors; each time this was done in the same way; the door was opened and closed as the individual entered and exited the room being monitored. The instrumentation was left in the same position throughout the testing period. Keeping both the windows and doors closed (except for a brief period) allows the researcher to assume air velocities within the room were below $0.01 \mathrm{~m} / \mathrm{s}^{6}$.

\section{Equipment}

Internal Globe/Operative Temperature - A black globe thermometer $(40 \mathrm{~mm} \varnothing)$ was used with a mercury thermometer as the temperature probe. The sensor was set up on a tripod and positioned $1.8 \mathrm{~m}$ from the glazed façade and set at $1.2 \mathrm{~m}$ above the floor level in all four rooms being monitored (Figure 5.).

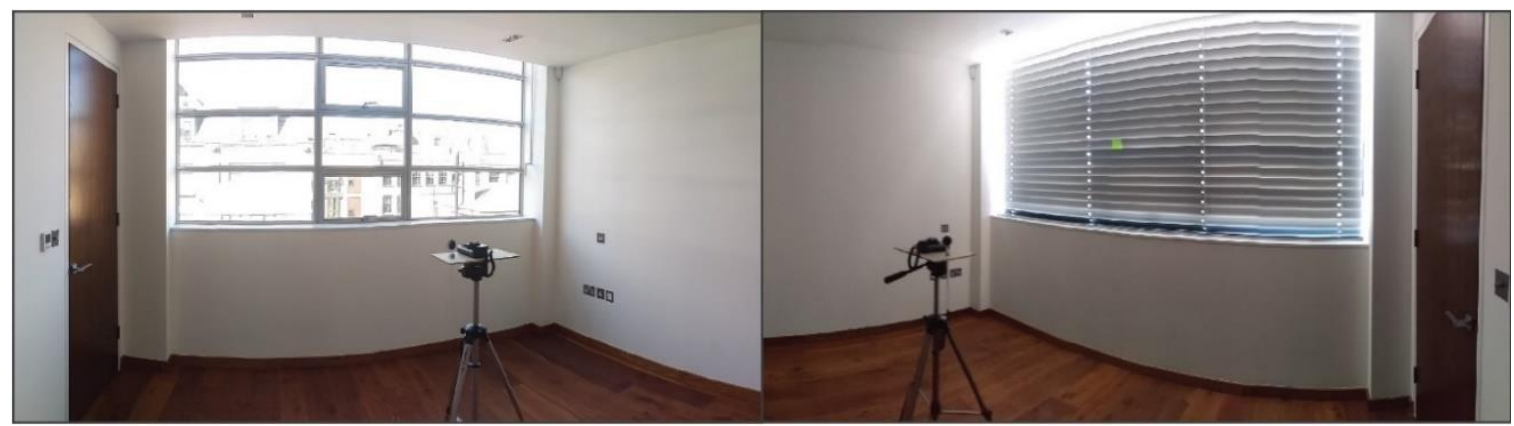

Bedroom A: Control Room (No Blind Installed/ Unshaded)

Bedroom B: 80mm Aluminium Venetian Blind

Figure 5. Equipment Setup 
External Air Temperature - A hand held air temperature sensor were situated on the ground floor outside the apartment building. The location of the sensor was moved to keep the air temperature sensor away from direct solar radiation to prevent the metal probe being affected by radiant heat.

Diagrams for the sensor setups are provided in Figure 6.

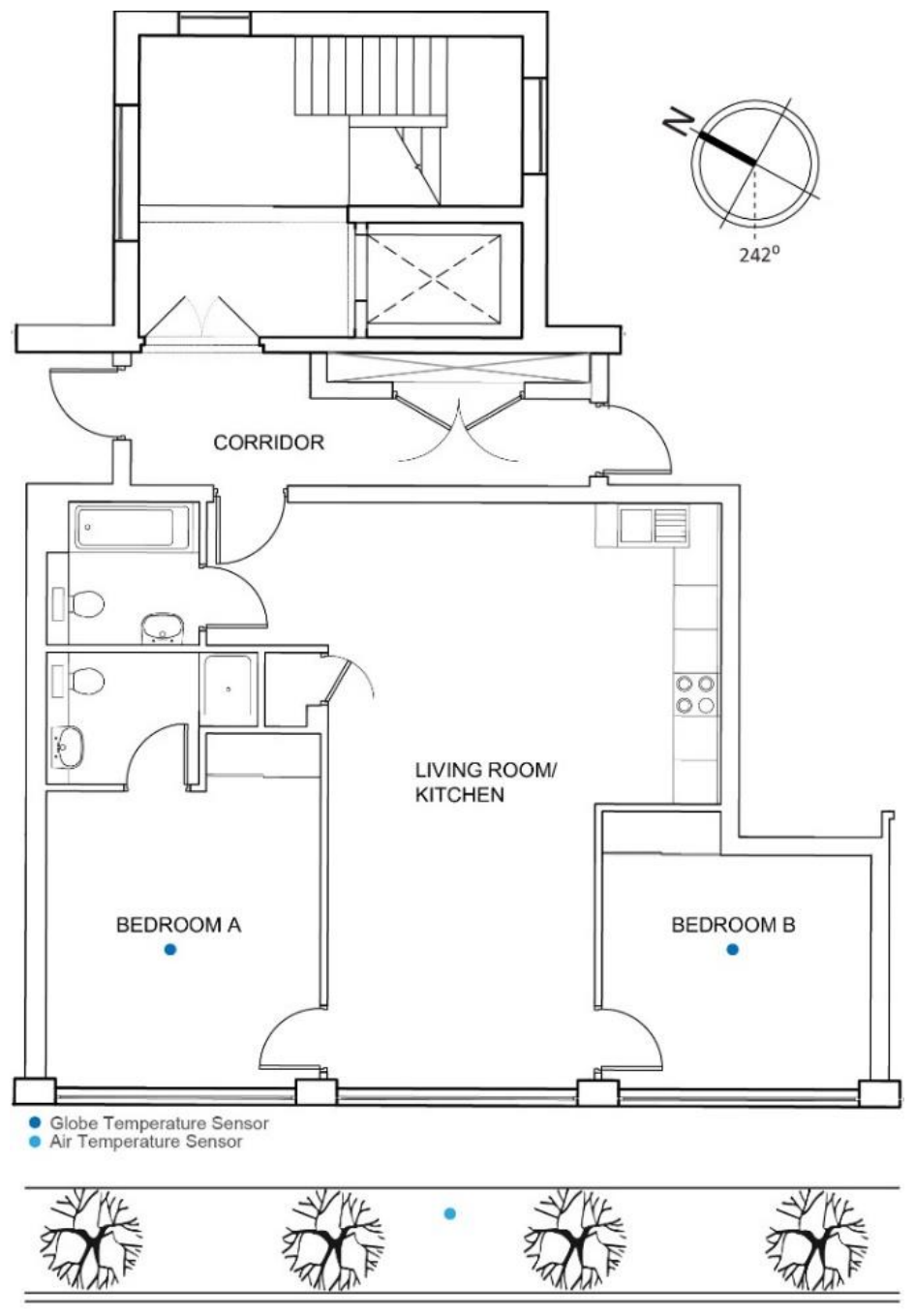

Figure 6. Sensor Layout

\section{Analysis and Results}

Internal and external temperature data were collected over a period of twenty days between August and October 2016. Out of these, data from fourteen of the twenty days met the quality requirements outlined by the data collection procedure and were used for analysis.

\section{External Weather Conditions}

Peak external air temperatures were reviewed to establish the variation in external weather conditions during the data collection period. The maximum external air temperatures were grouped into $15-20^{\circ} \mathrm{C}, 20-25^{\circ} \mathrm{C}$ and $25^{\circ} \mathrm{C}+$. An equal distribution in the number of days that peak within these temperature thresholds would ensure that the testing was representational of typical summer/ autumn weather conditions. Daily observations were made regarding external wind velocities which were considered calm during data collection. 
- Over the 14 days where data was used to compare internally shaded rooms and unshaded rooms, maximum external temperatures exceeded $25^{\circ} \mathrm{C}$ on four days and on the remaining ten days the external maximum temperatures were evenly distributed between the remaining groups.

- Over the 11 days where data was used to compare externally shaded rooms and unshaded rooms, maximum external temperatures exceeded $25^{\circ} \mathrm{C}$ on two days, remained between 20 $-25^{\circ} \mathrm{C}$ for four days and for the remaining five days peaked between $15-20^{\circ} \mathrm{C}$.

Therefore, the maximum external temperatures were slightly cooler on the days when external shading data was collected in comparison to the days where internal shading data was collected, and the weather conditions were considered typical for summer/ autumn period in London.

\section{CIBSE TM52 Overheating Criteria}

The data collected was evaluated in relation to the overheating criteria set by CIBSE TM52. In order to evaluate the results an adaptive temperature threshold was defined for the following overheating criteria to be assessed against.

The adaptive temperature threshold considers the adaptive measures that occupants take to protect themselves from overheating (such as wearing lighter clothing), the building category and the vulnerability of the occupants. These categories are defined by BS EN $15251^{41}$ and are given in CIBSE TM52.

\begin{tabular}{lll}
\hline Category & \multicolumn{1}{c}{ Definition } & $\begin{array}{c}\text { Suggested } \\
\text { Acceptable } \\
\text { Range (K) }\end{array}$ \\
\hline I & $\begin{array}{l}\text { High level of expectation only used for spaces occupied } \\
\text { by very sensitive and fragile persons }\end{array}$ & \pm 2 \\
\hline II & Normal expectation (for new buildings and renovations) & \pm 3 \\
\hline III & A moderate expectation (used for existing buildings) & \pm 4 \\
\hline IV & Values outside the criteria for the above categories & $>4$ \\
\hline & (only acceptable for a limited periods) & \\
\hline
\end{tabular}

Table 2. Categories for Suggested Acceptable Ranges of Temperature for Adaptive Temperature Thresholds In this study we have reviewed the criteria against the Category II threshold (Table 2).

\section{Criterion 1: Number of Overheating Hours}

Criterion 1 looks to assess the frequency at which overheating occurs and limits the number of hours over the adaptive temperature threshold to $3 \%$.

Figure 7 presents the monitored hourly averaged operative temperatures $\left(T_{\mathrm{op}}\right)$ for the rooms without shading and the rooms with internal shading which are plotted against the exponentially weighted daily mean external air temperature $\left(T_{r m}\right)$ using equation 1 . The $\left(T_{r m}\right)$ considers the mean outdoor air temperature of the previous seven days and applies a heavier weighting to the days closest to the day in question. 
$T_{r m}=\frac{\left(T_{o d-1}+0.8 T_{o d-2}+0.6 T_{o d-3}+0.5 T_{o d-4}+0.4 T_{o d-5}+0.3 T_{o d-6}+0.2 T_{o d-7}\right)}{3.8}$

$\mathrm{T}_{\mathrm{od}-1}=$ Daily Mean External Temperature of the day before monitoring

$\mathrm{T}_{\mathrm{od}-2}=$ Daily Mean External Temperature two days before monitoring

Additional external air temperature data was acquired for the $T_{r m}$ calculation from the Met Office Weather Station located $2.8 \mathrm{~km}$ away at St. James Park, London. Daily Mean Temperature Data was used that related to the days monitored.

The $T_{\max }$ (dashed lines) are also given in Figure 7, which represent the adaptive comfort thresholds as per BS EN 15251, which is calculated using Equation 2. The methodology for this is given in BS EN 15251 which are derived from the exponentially weighted daily mean external air temperature $\left(T_{r m}\right)$, given by Equation 1, and the suggested acceptable range $(\mathrm{K})$ presented in Table 2.

$T_{\max }=0.33 T_{r m}+18.8+K$

Each scatter plot on the graph that exceeds the $T_{\max }$ limit by $1^{\circ} \mathrm{C}$ or more represents 1 hour of overheating as per criterion 1.

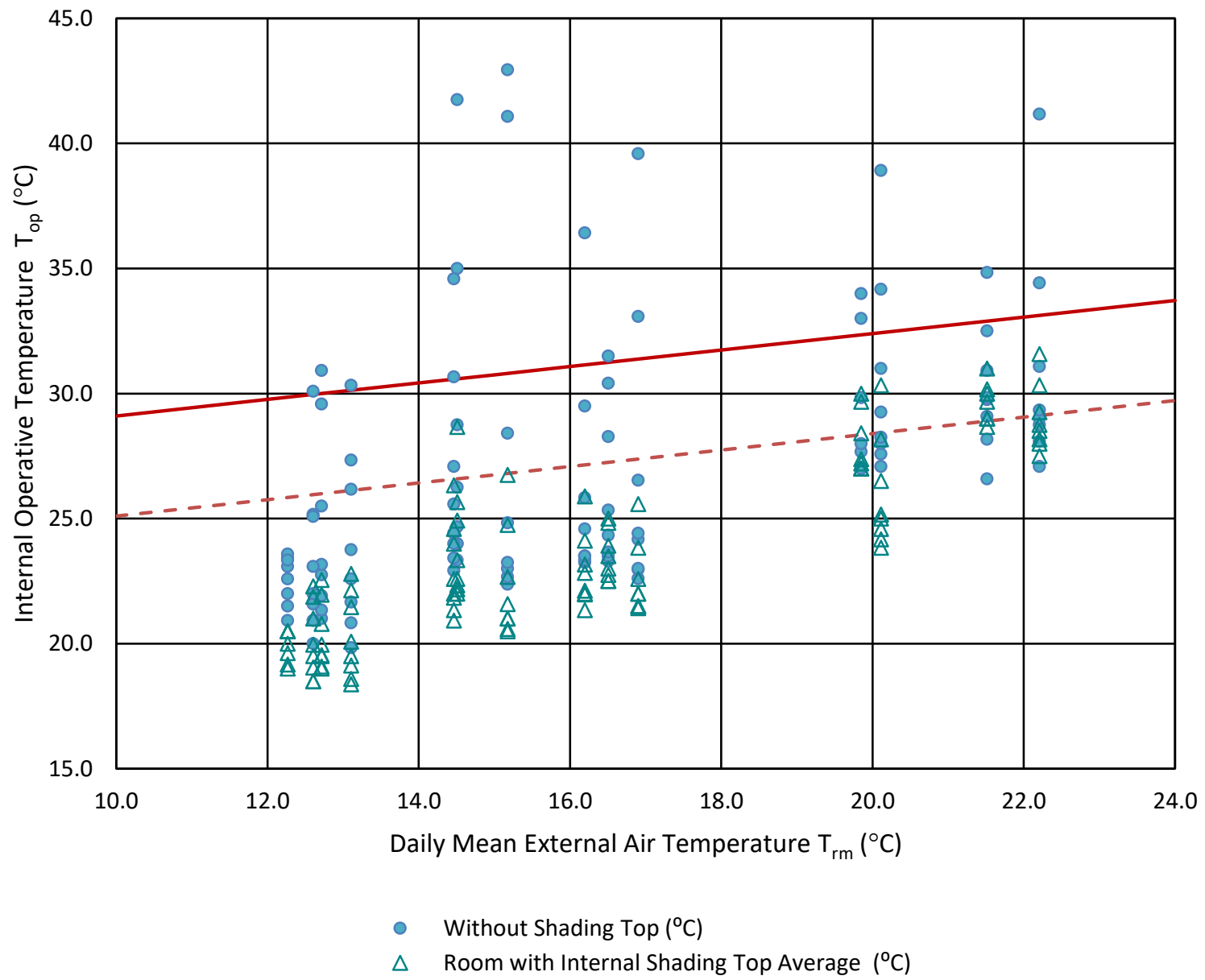

Figure 7. Scatter Plot of Hourly Averaged Indoor Operative Temperature (Top) plotted against the exponentially weighted daily mean external air temperature $\left(T_{r m}\right)$ with plots relating to rooms with no shading $(\bullet)$ and rooms with internal shading $(\Delta)$. (112 monitored readings) 


\section{No Shading vs Internal Shading}

- When the rooms without shading were evaluated almost $28.6 \%$ of the hours were equal to or exceeded the $T_{\max }$ by $1^{\circ} \mathrm{C}$, which is equivalent to 32 hours of the total 112 hours monitored.

- When the rooms were internally shaded $8 \%$ of the hours were equal to or exceeded the $T_{\max }$ by $1^{\circ} \mathrm{C}$, which is equivalent to 9 hours of the total 112 hours monitored.

Criterion 1 was not met in rooms without shading and rooms with internal shading were evaluated.

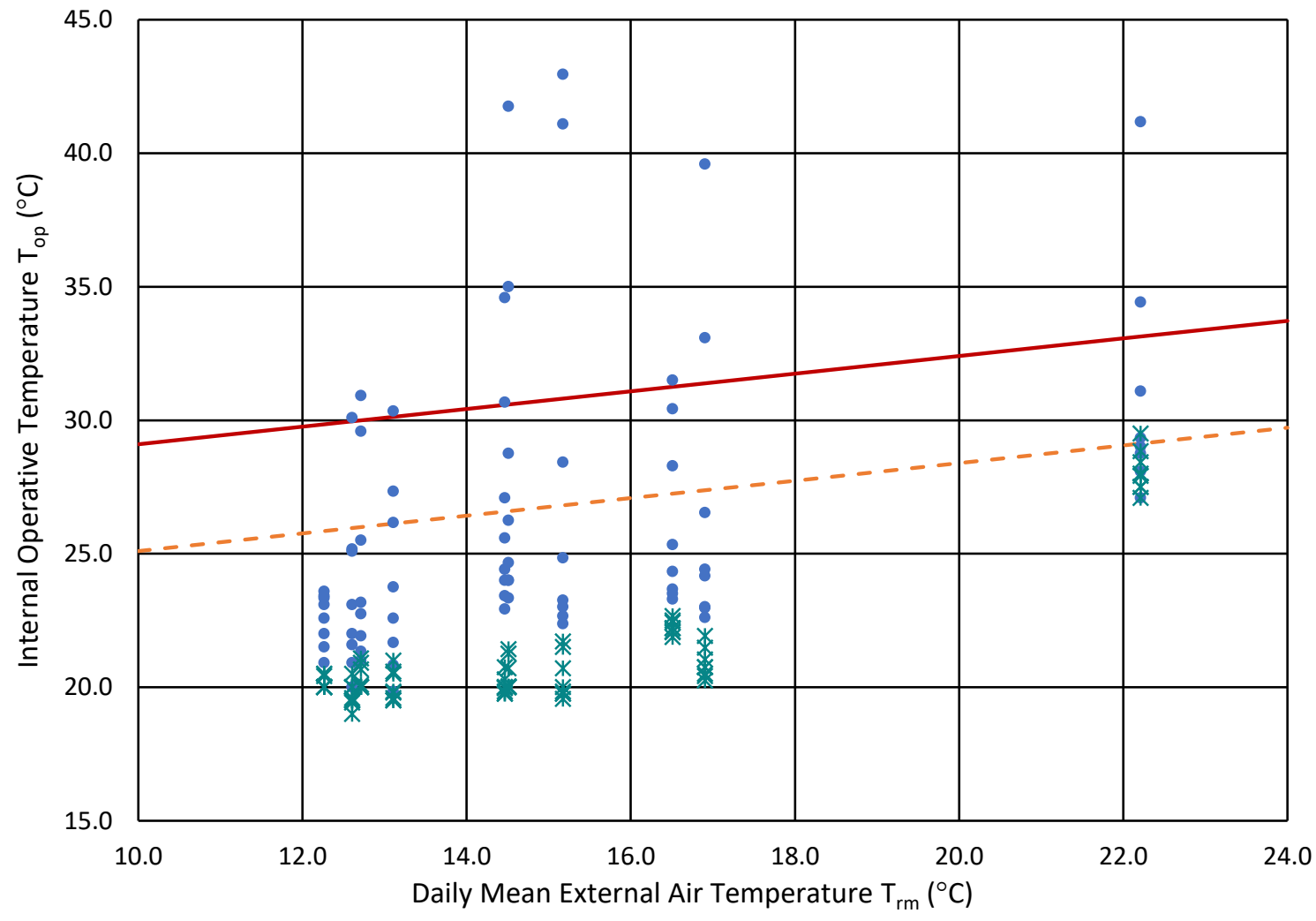

- Without Shading Top $\left({ }^{\circ} \mathrm{C}\right)$

* Room with External Shading Top Average $\left({ }^{\circ} \mathrm{C}\right)$

- - - Tmax (Category II)

Tupp (Category II)

Figure 8. Scatter Plot of Hourly Averaged Indoor Operative Temperature $\left(T_{o p}\right)$ plotted against the exponentially weighted daily mean external air temperature $\left(T_{r m}\right)$ with plots relating to rooms with no shading $(\bullet)$ and rooms with external shading $(\Delta)$. (80 monitored readings)

Figure 8 similarly presents the monitored hourly averaged operative temperatures ( $\left.T_{\text {op }}\right)$ for rooms without shading and rooms with external shading.

No Shading vs External Shading (Category II)

- When the rooms without shading were evaluated almost $26.3 \%$ of the hours were equal to or exceeded the $\mathrm{T}_{\max }$ by $1^{\circ} \mathrm{C}$, which is equivalent to 21 hours of the total 80 hours monitored.

- When the rooms were externally shaded the $T_{\max }$ was not exceeded. 
Criterion 1 was failed for rooms with no shading or internal shading but was passed when rooms had external shading. These results are further summarised in Table 3.

\begin{tabular}{lccc}
\hline Monitored Scenario & Monitored Hours & $\begin{array}{c}\text { Number of Hours } \\
\text { where the Tmax } \geq \\
\mathbf{1}^{\circ} \mathbf{C}\end{array}$ & $\begin{array}{c}\text { Percentage of } \\
\text { Monitored Hours where } \\
\text { the Tmax } \geq \mathbf{1}^{\circ} \mathbf{C}\end{array}$ \\
\hline No Shading & 112 & 32 & $28.60 \%$ \\
\hline Internal Shading & 80 & 9 & $8 \%$ \\
\hline No Shading & & 21 & $26.30 \%$ \\
\hline External Shading & & 0 & $0 \%$ \\
\hline
\end{tabular}

Table 3. Summary of the number of Overheating Hours and the percentage of Monitored Hours.

Both Figures 7 and 8 display measurements taken in August whilst the sun was at a high altitude and in October when the sun was at a lower altitude. In August, the $T_{r m}$ was $22^{\circ} \mathrm{C}$ when the peak $T_{\text {op }}$ was $41^{\circ} \mathrm{C}$ in the non-shaded room. In October, the $T_{r m}$ was $15^{\circ} \mathrm{C}$ when the peak Top in the non-shaded room was $43^{\circ} \mathrm{C}$. Due to the orientation of the building and the unobstructed window area the research team can hypothesise that the peak $T_{o p}\left(43^{\circ} \mathrm{C}\right)$ in the non-shaded room was measured when the $T_{r m}$ was lower because the lower sun angle allowed solar radiation to enter the building for a longer duration of time in October than in August. This subsequently caused overheating events in October as well as August.

\section{Criterion 2: Daily Weighted Exceedance}

The individual days monitored and scenarios where internal and external shading was used in rooms were reviewed. The weighted exceedance $\left(W_{e}\right)$ was calculated in relation to Equation 3 for each day monitored with either no shading, internal shading or external shading in use.

$$
\begin{aligned}
W_{e} & =\left(\sum h_{e} \times W F\right) \\
& =\left(h_{e^{0}} \times 0\right)+\left(h_{e^{1}} \times 1\right)+\left(h_{e^{2}} \times 2\right)+\left(h_{e^{3}} \times 3\right)
\end{aligned}
$$

The weighting factor (WF) is equal to zero if the difference between the actual monitored temperature ( $T_{\mathrm{op}}$ ) and the $T_{\max }$ is less than zero. However, if the difference between the actual monitored temperature ( $\left.T_{o p}\right)$ and the $T_{\max }$ is 1 then the $W F=1$ and if it is 2 then the $W F=2$ and so on. The $h_{e}$ represents the frequency (number of hours) of the WF. The $W_{e}$ should be less than or equal to 6 to pass the criterion. Further examples of how to calculate the Daily Weighted Exceedance are given in CIBSE: TM52 ${ }^{14}$.

- When the $W_{\mathrm{e}}$ for rooms without shading were evaluated, the recommended limit was exceeded on 7 of the 14 days monitored.

- During the 21 scenarios, across 14 days where rooms with internal shading systems were evaluated. The recommended $\mathrm{W}_{\mathrm{e}}$ was not exceeded in any of the scenarios.

- During the 16 scenarios, across 14 days where rooms with external shading systems were evaluated. The recommended $W_{\mathrm{e}}$ was not exceeded in any of the scenarios. 
Criterion 2 was not met when rooms had no shading device, but the criteria was passed when rooms had either internal or external shading.

\section{Criterion 3: Absolute Maximum Daily Temperature}

Figures 7 and 8 also present the absolute maximum temperature that should be experienced within a day termed $\left(T_{\text {upp }}\right)$, this is defined as the $T_{\max }$ plus $4 \mathrm{~K}$.

\section{No Shading vs Internal Shading}

Figure 7 compares rooms without shading and rooms with internal shading.

- When rooms with no shading were evaluated the $T_{\text {upp }}$ was exceeded on 13 out of the 14 days monitored.

- When rooms with internal shading were evaluated the $T_{\text {upp }}$ was not exceeded.

\section{No Shading vs External Shading}

Figure 8 compares the rooms without shading and rooms with external shading.

- When rooms with no shading were evaluated the $T_{\text {upp }}$ was exceeded on 9 of the 10 days monitored.

- Similarly, when rooms with external shading were evaluated the $T_{\text {upp }}$ was not exceeded.

Criterion 3 was failed when rooms had no shading device, but the criterion was passed when rooms had either internal or external shading.

\section{Operative Temperature Increase}

The operative temperature increase $(\Delta T)$ is defined by the difference between the maximum operative temperature $\left(T_{\max }\right)$ and the lowest operative temperature $\left(T_{\min }\right)$ collected within a test day $\left(T_{\max }-T_{\min }=\Delta T\right)$.

These temperature increases were statistically analysed as the temperatures taken at 8am differed in each room due to variation in thermal retention between rooms (as different blinds were installed in each room U-Values may have varied potentially differing the ventilation rates between rooms). The temperature increases for external air temperatures and internal operative temperature were calculated for each monitored period and are presented in Table 4. 


\begin{tabular}{|c|c|c|c|c|c|c|c|c|c|c|c|c|c|c|c|c|c|c|c|c|c|c|c|c|c|c|c|c|}
\hline \multirow[b]{4}{*}{$\begin{array}{c}\text { Testing } \\
\text { Day }\end{array}$} & \multirow[b]{4}{*}{ Date } & \multirow{3}{*}{\multicolumn{3}{|c|}{$\begin{array}{c}\text { Monitored } \\
\text { External Air } \\
\text { Temperatures }\left({ }^{\circ} \mathrm{C}\right)\end{array}$}} & \multicolumn{24}{|c|}{ Internal Operative Temperatures $\left({ }^{\circ} \mathrm{C}\right)$} \\
\hline & & & & & \multirow{2}{*}{\multicolumn{3}{|c|}{ No Shading }} & \multicolumn{12}{|c|}{ Internal Shading } & \multicolumn{9}{|c|}{ ternal Shading } \\
\hline & & & & & & & & \multicolumn{3}{|c|}{$\begin{array}{l}\text { Aluminium } \\
\text { Venetian }\end{array}$} & \multicolumn{3}{|c|}{$\begin{array}{c}\text { Aluminium } \\
\text { Venetian at } 45^{\circ}\end{array}$} & \multicolumn{3}{|c|}{ Fabric 1} & \multicolumn{3}{|c|}{ Fabric 2} & \multicolumn{3}{|c|}{$\begin{array}{l}\text { Aluminium } \\
\text { Venetian }\end{array}$} & \multicolumn{3}{|c|}{$\begin{array}{c}\text { Aluminium } \\
\text { Venetian at } 45^{\circ} \\
\end{array}$} & \multicolumn{3}{|c|}{ Fabric 1} \\
\hline & & $T_{\min }$ & $T_{\max }$ & $\Delta \mathrm{T}$ & $T_{\min }$ & $T_{\max }$ & $\Delta \mathrm{T}$ & $T_{\min }$ & $T_{\max }$ & $\Delta \mathrm{T}$ & $T_{\min }$ & $T_{\max }$ & $\Delta \mathrm{T}$ & $T_{\min }$ & $T_{\max }$ & $\Delta \mathrm{T}$ & $T_{\min }$ & $T_{\max }$ & $\Delta \mathrm{T}$ & $T_{\min }$ & $T_{\max }$ & $\Delta \mathrm{T}$ & $T_{\min }$ & $T_{\max }$ & $\Delta \mathrm{T}$ & $T_{\min }$ & $T_{\max }$ & $\Delta \mathrm{T}$ \\
\hline Day 1 & 24.08 .16 & 22.4 & 34.2 & 11.8 & $26.5 *$ & $45.0 *$ & 18.5 & 23.5 & $31.0 *$ & 7.5 & - & - & - & - & - & 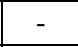 & - & - & - & - & - & - & - & - & - & - & - & - \\
\hline Day 2 & 25.08 .16 & 22.5 & 31.1 & 8.6 & 25.0 & $40.0^{*}$ & 15.0 & 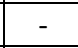 & - & & - & - & - & $28.0 *$ & $31.0^{*}$ & 3.0 & 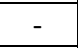 & 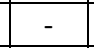 & - & $28.0^{*}$ & $28.0^{*}$ & 0.0 & & - & 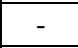 & - & - & - \\
\hline Day 3 & 26.08 .16 & 20.8 & 27.9 & 7.1 & $27.0 *$ & $47.5 *$ & 20.5 & - & - & - & - & - & - & $27.0 *$ & $32.0 *$ & 5.0 & - & - & - & - & - & - & $27.0 *$ & $29.5 *$ & 2.5 & - & - & - \\
\hline Day 4 & 08.09 .16 & 19.7 & 25.5 & 5.8 & $27.0 *$ & $36.0 *$ & \begin{tabular}{|l|}
9.0 \\
\end{tabular} & $26.0^{*}$ & $30.0 *$ & \begin{tabular}{|l|}
4.0 \\
\end{tabular} & - & - & - & - & - & - & $27.0 *$ & $31.0 *$ & \begin{tabular}{|l|}
4.0 \\
\end{tabular} & - & - & - & - & - & - & - & - & - \\
\hline Day 5 & 28.09 .16 & 14.3 & 23.2 & 8.9 & 23.0 & $39.0 *$ & 16.0 & 21.0 & $26.0^{*}$ & 5.0 & - & - & - & 21.5 & 27.0 & 5.5 & 21.0 & $26.5 *$ & 5.5 & - & 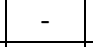 & - & - & - & - & - & - & 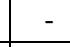 \\
\hline Day 6 & 29.09 .16 & \begin{tabular}{|l|} 
\\
\end{tabular} & 20.4 & 3.5 & 23.0 & $33.5 *$ & 10.5 & - & - & - & - & - & - & - & - & - & 22.5 & 25.0 & 2.5 & 21.0 & 22.5 & 1.5 & 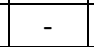 & - & - & 22.0 & 24.0 & 2.0 \\
\hline Day 7 & 30.09 .16 & 13.2 & 20.1 & \begin{tabular}{|l|l|}
6.9 \\
\end{tabular} & 22.5 & $42.0 *$ & \begin{tabular}{|l|}
19.5 \\
\end{tabular} & - & - & - & - & - & - & - & - & - & 21.0 & $26.5 *$ & 5.5 & 20.0 & 21.5 & 1.5 & - & - & - & 20.5 & 23.0 & 2.5 \\
\hline Day 8 & 03.10 .16 & 10.5 & 21.4 & 10.9 & 22.0 & $45.0 *$ & 23.0 & - & - & - & - & 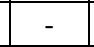 & - & - & - & - & 20.5 & $28.0 *$ & 7.5 & 20.0 & 22.5 & 2.5 & - & - & - & 19.0 & $26.0^{*}$ & 7.0 \\
\hline Day 9 & 05.10 .16 & 13.0 & 20.5 & 7.5 & 23.0 & $44.0 *$ & 21.0 & - & - & - & 22.5 & $30.5 *$ & 8.5 & - & - & - & - & - & - & 20.0 & 21.0 & 1.0 & - & - & - & 20.0 & 22.0 & 2.0 \\
\hline Day 10 & 06.10 .16 & 13.5 & 18.7 & 5.2 & 22.5 & $39.0 *$ & 16.5 & - & - & - & 20.5 & $27.0 *$ & 6.5 & - & - & - & - & - & - & 20.0 & 20.5 & 0.5 & - & - & - & 19.5 & 21.0 & 1.5 \\
\hline Day 11 & 11.10 .16 & 9.9 & 18.2 & 8.3 & 19.5 & $38.0 *$ & 18.5 & 18.5 & 24.0 & 5.5 & - & - & - & 18.0 & 23.0 & 5.0 & - & - & - & - & - & - & 19.5 & 21.5 & 2.0 & - & - & 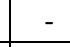 \\
\hline Day 12 & 12.10 .16 & \begin{tabular}{|l|}
12.3 \\
\end{tabular} & 16.4 & \begin{tabular}{|l|}
4.1 \\
\end{tabular} & 21.0 & $37.0 *$ & 16.0 & \begin{tabular}{|l|l}
19.5 \\
\end{tabular} & 24.0 & \begin{tabular}{|l|}
4.5 \\
\end{tabular} & 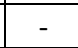 & - & 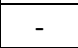 & 18.5 & 22.5 & \begin{tabular}{|l|}
4.0 \\
\end{tabular} & - & - & - & - & - & - & 20.0 & 21.5 & \begin{tabular}{|l|}
1.5 \\
\end{tabular} & - & - & - \\
\hline Day 13 & 13.10 .16 & 11.1 & 16.0 & 4.9 & 20.0 & $32.5 *$ & 12.5 & - & - & - & 19.0 & 24.0 & \begin{tabular}{|l|} 
\\
\end{tabular} & 18.0 & 21.5 & 3.5 & - & - & - & - & - & - & 19.0 & 21.0 & \begin{tabular}{|l|} 
\\
\end{tabular} & - & - & - \\
\hline Day 14 & 14.10 .16 & \begin{tabular}{|l|}
4.5 \\
\end{tabular} & 15.3 & 10.8 & 20.5 & 24.5 & 4.0 & - & - & - & 19.0 & 21.0 & \begin{tabular}{|l|}
2.0 \\
\end{tabular} & 19.0 & 20.0 & 1.0 & - & - & - & - & - & - & 20.0 & 20.5 & 0.5 & - & - & - \\
\hline
\end{tabular}

Table 4. Minimum Temperatures $\left(T_{\min }\right)$, Maximum Temperatures $\left(T_{\max }\right)$ and Temperature Increase $(\Delta T)$ of External Air Temperatures and Internal Operative Temperatures over 14 Days between $8 \mathrm{am}-4 \mathrm{pm}$. The solar shading specified was fixed at a closed lowered position or a closed $45^{\circ}$ angle for the entirety of the day. 
The operative temperature increases between $8 \mathrm{am}$ and $4 \mathrm{pm}$ were statistically compared using a Paired t-Test to observe whether internal and external shading have a significant impact on the operative temperature increase in comparison to the control room. Where data were collected for more than one internal or external shading type the temperature increase $(\Delta T)$ was averaged before the Paired t-test comparison was conducted.

\begin{tabular}{lllllllll} 
& \multicolumn{8}{c}{$\begin{array}{c}95 \% \text { Confidence } \\
\text { Interval of } \\
\text { Difference }\end{array}$} \\
\hline Pair & $\begin{array}{l}\text { No. of } \\
\text { Paired } \\
\text { Samples }\end{array}$ & $\begin{array}{l}\text { Mean } \\
\left({ }^{\circ} \mathrm{C}\right)\end{array}$ & $\begin{array}{l}\text { SD } \\
\left({ }^{\circ} \mathrm{C}\right)\end{array}$ & $\begin{array}{l}\text { Lower } \\
\left({ }^{\circ} \mathrm{C}\right)\end{array}$ & $\begin{array}{l}\text { Upper } \\
\left({ }^{\circ} \mathrm{C}\right)\end{array}$ & $\begin{array}{l}\mathrm{t}- \\
\text { statistic } \\
\left({ }^{\circ} \mathrm{C}\right)\end{array}$ & $\begin{array}{l}\text { Deg. of } \\
\text { Freedom }\end{array}$ & $p$ \\
\hline $\begin{array}{l}\text { No Shading v } \\
\text { Internal Shading }\end{array}$ & 14 & 10.71 & 3.75 & 8.54 & 12.88 & 10.68 & 13 & $<0.001^{*}$ \\
\hline $\begin{array}{l}\text { No Shading vs } \\
\text { External Shading }\end{array}$ & 11 & 14.32 & 4.86 & 11.06 & 17.58 & 9.80 & 10 & $<0.001^{*}$ \\
\hline
\end{tabular}

*Level of Significance $<0.05$

Table 5. Means Comparison Paired t-Test of the averaged difference in Operative Temperature Increase $(\Delta T)$ between rooms without shading and rooms with internal shading and rooms without shading and rooms with external shading.

Table 5 and Figure 9 represent the findings from the statistical review. These indicate that in all cases there was a significant difference between operative temperature increase $(\Delta T)$ when both internal and external shading were used and compared with the temperature increases monitored in the control room.

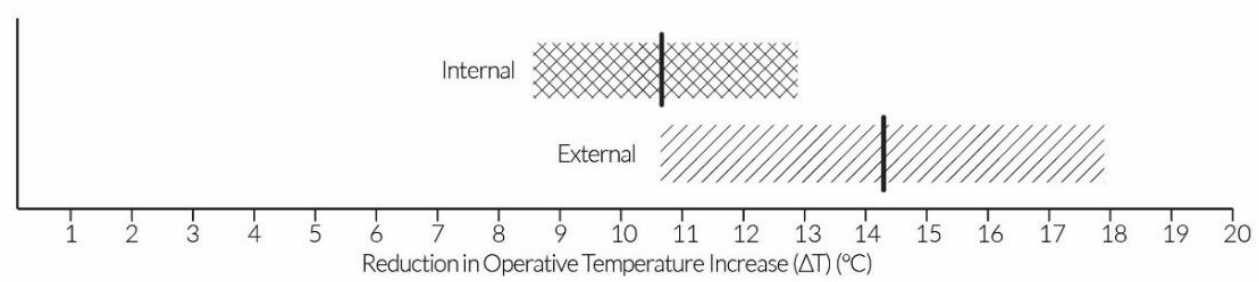

Figure 9. 95\% Confidence interval and mean values of internally shaded rooms and external shaded rooms reduction in operative temperature increase compared with an unshaded room.

If the experiment was to be carried out again in the same location, with external conditions within the same parameters and with the same window and blind opening and closing actions, we can say with $95 \%$ confidence that:

- Internal Shading will reduce the operative temperature increase by between $8.54^{\circ} \mathrm{C}$ $-12.88^{\circ} \mathrm{C}$. The room with internal shading would therefore be $8.54^{\circ} \mathrm{C}-12.88^{\circ} \mathrm{C}$ cooler than a room without shading.

- External Shading would reduce the operative temperature increase in the room by between $11.06^{\circ} \mathrm{C}-17.58^{\circ} \mathrm{C}$. The room with external shading would therefore be $11.06^{\circ} \mathrm{C}-17.58^{\circ} \mathrm{C}$ cooler than a room without shading. 
External shading has been found to reduce operative temperature increase more than internal shading. However internal shading has also been able to significantly reduce the operative temperature increase - by 73 - 77\% when compared to the operative temperature reduction achieved by external shading. This indicates that internal shading can be three quarters as effective as external shading within this scenario.

\section{Discussion}

In the design stage of the building, installation of external shading was discouraged on the basis that it would not be a necessity as the developer was informed the glazing alone would obviate the requirement for solar shading. For this reason, the installation of external shading was considered unjustified due to its impact on the aesthetics of the building. Even though overheating was identified post-construction retrofit of external shading was not feasible as there were planning restrictions in place, even though the building was not listed. However, internal shading was included prior to handing the property over to the occupants.

It is important to acknowledge that several other design factors can also contribute to overheating and these need to be considered and evaluated before construction or re-fit. These include: the location and orientation of the building, ceiling height, room depth, insulation and potential for air leakage, thermal mass of the building, façade design layout, hot water distribution layout, internal heat loads from occupants and equipment, and the ability to cross ventilate the building. Further to this how an occupant uses the building has a significant impact. This study emulates one occupancy profile within the restrictions of real-world data collection.

The results identify that the combination of opening windows at night and the closure of shading devices during the day can provide a significant thermal benefit to occupants. However, these behaviours will also come at a cost when considering an occupant's overall comfort: increased exposure to external noise at night and a reduction in the availability of natural lighting during the day. These can be detrimental to sleep quality and an individual's health and well-being. However, the lack of night-time temperature data meant the researcher could not evaluate the bedrooms according to TM59 which can be used to identify the extent of night-time overheating. The inter-relationship between glazing, shading, ventilation, daylighting and noise exposure needs to be collectively evaluated at the building design stage to ensure the appropriate design of an effective façade management strategy.

\section{Conclusion}

Solar shading combined with night-time ventilation in this case was found to reduce the risk of overheating by reducing the operative temperature increase throughout the day. External shading is observed to be most efficient when assessed against CIBSE TM52 Overheating Criteria. Rooms with external shading met all three of the criteria within CIBSE TM52 Overheating Criteria whereas rooms with no shading failed to meet all 3-criteria.

Furthermore, overheating events were found to have occurred in October as well as August when the $T_{r m}$ was lower which is hypothesized to be caused by low angle sun entering the building for a longer duration of time during the day. 
Although internal shading is deemed less effective, as it only passed criteria 2 and 3 , this study demonstrated that it can achieve as much as $73 \%$ of the operative temperature reduction that external shading systems can achieve.

Although external solar shading can be more effective than internal shading it is not a widespread practice in the UK as windows often open outwards, which may prevent the opening of windows when external shading is situated close to the building façade.

A further benefit of solar shading as a mitigation device against overheating is its dynamic quality. When shading is deployed it can reject solar gains through improving the heat rejection properties of a window system (referred to as the $g_{\text {tot }}$ when combined with shading). However static shading systems, such as brise soleil and overhangs, could create an energy penalty by rejecting solar heat gains in colder months which are valuable contributor to reducing the heating energy required to warm our buildings.

Nevertheless, it is acknowledged that shading combined with night-time ventilation is a passive method of reducing overheating which could subsequently reduce energy consumption in years to come through reducing the need for active cooling. Behavioural barriers can negate the potential for these passive energy saving measures, users need to be educated in how to protect themselves in heat wave conditions and how to effectively incorporate these measures into their daily lives.

Appropriate specification of glazing systems is vital in combatting the issues of overheating. Increasing the window opening areas is essential for effective night-time ventilation of buildings, particularly in single aspect buildings and finally, clarity is needed on the importance of g-value specification at the design stage to ensure buildings are designed with dynamic shading solutions, so they do not overheat.

\section{Acknowledgements}

The Authors would like to thank Rupert Cain, Alex Gutteridge, Harry Ketley, Diana Csilla Toth, Nick Teixeira and Senez Oznacar from London South Bank University for their support in conducting measurements during such warm conditions.

\section{Funding}

The Author(s) declare that this research was funded by The British Blinds and Shutters Association and London South Bank University as part of a PhD programme. 


\section{References}

1. Committee on Climate Change. UK Climate Change Risk Assessment 2017 Synthesis report: priorities for the next five years. UK, 2016.

2. Zero Carbon Hub. Overheating in Homes: The Big Picture. UK, 2015.

3. Building Research Establishment, Department of Energy and Climate Change. Energy Follow Up Survey, 2011. Report 7: Thermal Comfort \& Overheating. 3rd Edition. UK Data Service. 2013.

4. Seguro F and Palmer J. Solar shading impact. Report, The National Energy Foundation, UK, June 2016.

5. House of Commons Environmental Audit Committee. Environmental Audit Committee Heatwaves : adapting to climate change, https://publications.parliament.uk/pa/cm201719/cmselect/cmenvaud/826/826.pdf (2018, accessed 28 November 2018)

6. The Chartered Institution of Building Services Engineers. CIBSE Guide A: Environmental Design, 8th ed. Great Britain. March 2015.

7. Taylor M, Preventing Overheating. UK: Good Homes Alliance, 2014

8. THE EUROPEAN PARLIAMENT AND THE COUNCIL OF THE EUROPEAN UNION. REGULATION (EU) 2018/841 OF THE EUROPEAN PARLIAMENT AND OF THE COUNCIL of 30 May 2018 on the inclusion of greenhouse gas emissions and removals from land use, land use change and forestry in the 2030 climate and energy framework, and amending Regulation (EU) No 525/2013 and Decision No 529/2013/EU. Off J Eur Union. 2018.

9. Wouter, W., Dolmans, D., Dutoo, G., Hall, A., Seppänen, O. and Beck, W. Solar shading: How to integrate solar shading in sustainable buildings Guidebook No 12. Brussels, Belgium: REHVA, Federation of European Heating and Air-conditioning Associations, 2010.

10. International Energy Agency. Technology Roadmap energy efficient building envelopes. https://www.iea.org/publications/freepublications/publication/TechnologyRoadmapEn ergyEfficientBuildingEnvelopes.pdf (2013, accessed 28 November 2018)

11. Building Research Establishment, Department of Energy and Climate Change. Study on Energy Use by Air- Conditioning: Annex A Literature Search. https://www.bre.co.uk/filelibrary/pdf/projects/aircon-energyuse/A AirConditioningEnergyUseAnnexAFinal.pdf (2016, accessed 28 November 2018)

12. Murphy J, Sexton D, Jenkins G, Boorman P, Booth B, Brown K, et al. UK Climate Projections science report: Climate change projections. UK Climate Projections, https://www.nuneatonandbedworth.gov.uk/download/downloads/id/1515/g11 climate change projections - part 1 2010.pdf (2009, accessed 28 November 2018)

13. Lomas KJ, Porritt SM. Overheating in buildings: lessons from research. Build Res Inf. 2017;45(1-2):1-18 DOI: 10.1080/09613218.2017.1256136

14. The Chartered Institution of Building Services Engineers. The limits of thermal comfort: avoiding overheating in European buildings. CIBSE TM52. Great Britain. July 2013.

15. The Chartered Institution of Building Services Engineers. Design methodology for the assessment of overheating risk in homes. CIBSE TM59. Great Britain. April 2017.

16. Office for National Statistics. Characteristics of Home Workers. 2014.; 2014 
17. Felstead A, Henseke G. Assessing the growth of remote working and its consequences for effort, well-being and work-life balance. New Technol Work Employ. 2017;32(3):195212. DOI:10.1111/ntwe.12097.

18. Mavrogianni A, Pathan A, Oikonomou E, Biddulph P, Symonds P, Davies M. Inhabitant actions and summer overheating risk in London dwellings. Build Res Inf. 2016; 45(12):119-42. DOI: 10.1080/09613218.2016.1208431

19. Gupta R, Barnfield L, Gregg M. Overheating in care settings: magnitude, causes, preparedness and remedies. Build Res Inf. 2017;45(1-2):83-101.

DOI:10.1080/09613218.2016.1227923.

20. Roberts BM, Allinson D, Lomas KJ, Roberts BM, Allinson D. A Matched Pair of Test Houses With Synthetic Occupants to Investigate Summertime Overheating. SDAR* J Sustain Des Appl Res. 2018;6(1, Article 4). DOI:10.21427/D70N8S.

21. Zero Carbon Hub. Overheating in Homes The Big Picture. http://www.zerocarbonhub.org/sites/default/files/resources/reports/ZCHOverheatingInHomes-TheBigPicture-01.1.pdf (2015, accessed 28 November 2018)

22. Tzempelikos A, Bessoudo M, Athienitis AK, Zmeureanu R. Indoor thermal environmental conditions near glazed facades with shading devices - Part II: Thermal comfort simulation and impact of glazing and shading properties. Build Environ 2010; 45(11):2517-25. DOI: 10.1016/j.buildenv.2010.05.014

23. Public Health England NHS. Heatwave plan for England Making the case: the impact of heat on health - now and in the future.

https://www.gov.uk/government/uploads/system/uploads/attachment data/file/4295 72/Heatwave plan -Making the case - 2015.pdf (2015, accessed 28 November 2018)

24. Greater London Authority. THE LONDON PLAN The Spatial Development Strategy for London Consolidated with consolidated alterations since 2011.

https://www.london.gov.uk/sites/default/files/the london plan malp final for web 0 606 0.pdf (2016, accessed 28 November 2018)

25. National Energy Foundation. SOLAR SHADING IMPACT, http://www.nef.org.uk/themes/site themes/agile records/images/uploads/BBSA-NEFSolar-Shading-Impact-Report-June-2016.pdf (2016, accessed 28 November 2018)

26. Alders EE. Adaptive heating, ventilation and solar shading for dwellings. Archit Sci Rev. 2017;60(3):150-166. DOI:10.1080/00038628.2017.1300132.

27. Hutchins M. High Performance Dynamic Shading Solutions for Energy Efficiency and Comfort in Buildings Executive Summary.; 2015. http://www.esso.com/images/downloads/Downloads publications/ES-SO 15-498 ExecutiveSummary September-2015.pdf.

28. Larsen $\mathrm{T}$, Jensen $\mathrm{R}$, Daniels $\mathrm{O}$. The comfort houses - Measurements and analysis of the indoor environment and energy consumption in 8 passive houses 2008-2011: Report for the Department of Civil Engineering, Aalborg University. Report No. 145, 2012. Aalborg: Aalborg University.

29. Building Research Establishment (BRE). Comfort without Air-Conditioning in Refurbished Offices - an Assessment of Possibilities.

30. The British Blind and Shutter Association. Guide to Low Energy Shading, www.shadeit.org.uk/wp-content/uploads/2016/09/BBSA-Guide-to-low-energyshading.pdf (2015, accessed 28 November 2018)

31. European Solar Shading Organisation. SOLAR SHADING FOR LOW ENERGY AND HEALTHY BUILDINGS, http://www.es-so.com/images/downloads/Downloads publications/ESSO Technical GuideBook BD Final.pdf (2018, accessed 28 November 2018) 
32. Littlefair PJ. Solar Shading of Buildings. Report no. BR364, Building Research Establishment (BRE), 2017. UK

33. Dubois M.-C. Solar Shading for Low Energy Use and Daylight Quality in Offices:

Simulations, Measurements and Design Tools. Report No TABK--01/1023, 2001. Sweden: Lund University.

34. Acoustic and Noise Consultants. Acoustics Ventilation and Overheating Residential Design Guide: Draft Copy for Consultation. February 2018. http://www.association-ofnoise-consultants.co.uk/wp-content/uploads/2018/02/AVO-Guide-draft-forconsultation.pdf (2018, accessed 21 February 2018)

35. Paule B, Boutillier J, Pantet S. Global Lighting Performance. http://www.esso.com/images/downloads/Downloads\%20publications/ESTIA Study English ver $30 . p$ df (2015, accessed 28 November 2018)

36. Van Den Wymelenberg K. Patterns of occupant interaction with window blinds: A literature review. Energy Build. 2012;51(2012):165-76. DOI: 10.1016/j.enbuild.2012.05.008

37. Building Research Establishment, Department of Energy and Climate Change. SAP 2012 The Governments Standard Assessment Procedure for Energy Rating of Dwellings 2012 Edition.; 2014. www.bre.co.uk/sap2012. (2014, accessed 28 November 2018)

38. Pathan A, Mavrogianni A, Summerfield A, Oreszczyn T, Davies M. Monitoring summer indoor overheating in the London housing stock. Energy Build. 2017;141:361-378. DOI:10.1016/j.enbuild.2017.02.049.

39. Warner Lofts. Anello Building, https://static1.squarespace.com/static/54c629d7e4b0707229799042/t/573b2771cf80a 163307939f4/1463494526910/anello.pdf (2016, accessed 28 November 2018)

40. BSI. BS EN 14501: 2005 Blinds and shutters. Thermal and visual comfort Performance characteristics and classification.

41. BSI. BS EN 15251: 2007 Indoor environmental input parameters for design and assessment of energy performance of buildings addressing indoor air quality, thermal environment, lighting and acoustics. 